\title{
Other Abbreviations
}

\author{
anal. ed. analytical edition \\ encycl. encyclopedia \\ Ivs. leaves \\ prog. program \\ UC University of California
}


